\title{
$\mathscr{2}$
}

\section{Acknowledgments for the Revised Edition}

In THE INTRODUCTION TO THIS NEW EDition of Silent Looms, I wanted to show that while many elements of life in San Pedro Sacatepéquez had changed, overall, the town was much the same. In that spirit, I am delighted to say that most of the people I thanked in 1980 are those to whom I owe my gratitude now. The hospitality of the entire Orozco family buoyed me through a potentially lonely field visit. My "co-compadres," Tono and Luci Orozco, housed me, fed me, and indulged my endless questions. Reyna and Claudio Gonzalez, who had thought me dead after so many years away, rallied from their shock to be faithful guides to the new San Pedro economies. The family of Doña Eve Orozco swooped me up in San José Caben, giving me many enjoyable hours chatting about the post-weaving revolution in their town. In my investigation of Pacas, Doña Melvy Fuentes welcomed me into her store and talked freely about the business. The family of Don Gumercindo Fuentes volunteered to do a survey of Pacas for me. Chata Orozco was my guide through the smuggling business. There are many others who made this visit such a pleasure: Dr. Julio Roberto Fuentes, Doña Turivia de Leon, Profesora Tony Merida, Alcalde Edwin Honero Bravo Soto, Don Saul Navarro, and many other Sampedranos.

In the States, I must thank Paul Shankman for his continued support and honest criticism. Robert Carlsen provided encouragement and a Guatemalanist's perspective in his careful reading of the new introduction. Helayne Jones gave me thoughtful comments on the last draft. During a visit to San Pedro in late 1998, Linda Kelly sent me helpful corrections to a manuscript I had left behind with the Orozcos. As always, my husband, Michael C. Eh- 
lers, supported my being away (again). I am indebted to him for adding a businessman's head and an editor's eye to the new writing. The University of Denver sponsored my I 997 research with a Faculty Internationalization Grant. At the University of Texas Press, Theresa J. May has been a caring, sensitive editor. I am especially grateful to her for believing that Silent Looms merited a new edition.

My dear friend and adopted brother, Jerry Goldstein, who had so enhanced my original research in San Pedro in the i 970 , completed the circle in 1997 by driving me to San Pedro from his home in Panajachel. It was Jerry who, in 1985 , encouraged me to work in San Antonio Palopó, which then became my second highland field site. In countless field visits, we talked and laughed together, sharing stories about the two towns and all the people we knew. We were so fascinated by local life that we rarely paid attention to anything else, even when cable TV came to Panajachel in the early i 990 os. Sadly, this visit to Guatemala was to be the last one I shared with Jerry. In July 1998 he succumbed to AIDS after a twelve-year battle. 